\title{
THE USE OF MODELS IN OPTIMIZING THE FIELD CROP PRODUCTION IN AGRICULTURAL ENTERPRISE
}

\author{
Mihajlo Munćan
}

\begin{abstract}
The full use of resource capacities of agricultural enterprises favorably affects the general increase in economic efficiency and rational production making them more competitive in the market. This creates the need for constant improvement of business strategies that uses all available resources to create the most profitable production.

The main objective of this study was to find the ideal structure of production in agricultural enterprise and to enable the realization of maximum profit using the available production resources (land, mechanization, labor forces).

As the basic method of planning, this study used the simplex method of linear programming which gives the most profitable sowing structure after detailed analysis of resources and achieved results, based on the limitations and gross margin.

This work showed that the use of modern methods in production planning is one of the cheapest and safest methods for development of agricultural enterprises.
\end{abstract}

Key words: model, agricultural enterprises, resources, profit

\section{Introduction}

Great progress realized over the last 20 to 30 years in agriculture is not consequence solely of the global technical and technological improvement of the production process, but also of management methods and of the business management. Main features of these methods were:

- Profound and more frequent business analysis,

- Detailed and more precise planning of the production,

- Division of the enterprise into organizational units, even separate production lines and

- Dependence of the employees on the business results.

Successful management in modern conditions of economy requires among other things maximal adjustment of the business policy of an agricultural enterprise to the demands of the general business conditions.

For agriculture, and especially for field crop production, biological character is characteristic induced exclusively by biological traits of the plants, i.e. their physiological functions which cannot be influenced by the man, or if they can the influence is very moderate.

Therefore, in the process of field crop production, numerous factors occur which have very strong influence on organization of work processes, necessary capacity, structure and level of utilization of human labour and mechanization.

From the aspect of organization of field crop production, the following specific traits of agriculture should be taken into consideration:

- Duration of the work process and production process in agriculture don't coincide. Duration of process in agriculture is significantly shorter than production process, i.e. production process takes place mainly under the influence of environment factors, without the participation of the man;

- Agricultural production is production in the open, so weather conditions have significant influence of the organization of agriculture, since unfavourable weather conditions can not only impede execution of certain operations, but also to prevent them;

- Execution of certain work processes in field crop production is often conditioned by very short optimal agro-technical deadlines;

- Uneven scope of work operations during technological process of production cause incidence of labour peaks, which often has as a consequence engagement of great number of workers and mechanization for short time period, which outside these deadlines remains almost unutilized.

Because of stated specificities of this production, it is necessary to plan sowing for longer time period, even several years in advance. From that aspect, it can be concluded that planning of sowing structure is in the domain of strategic decision making and that use of methods of optimization is powerful tool for successful determination of future production structure.

\section{Research subject and goal}

Need for constant questioning of realized results of production is in a certain sense universal approach in relation to man and his accomplishments. No matter how favourable 
realized results are, it is considered as not so good so that they could be improved. Therefore, subject of this paper is finding of the optimal structure of field crop production in an agricultural enterprise located in South Banat (Serbia). Main characteristics of this enterprise are:

- It is located in the low land region;

- It disposes with 311 ha of plough land of equal quality and optimal parcel size;

- It is engaged in intensive field crop production;

- It is well equipped with necessary mechanization;

- There is possibility for engagement of necessary number of seasonal workers;

- Plough land is used exclusively for production of grain and industrial plants;

- Entire plough land surface is engaged for market oriented field crop production.

Objective of the study is to project, using modern methods of optimizing, primarily simplex method of linear programming, and optimal sowing structure in observed agricultural enterprise which would enable maximal use of resources and labour capacities at the disposal as well as mechanization, and by doing this to realize maximal business result expressed by gross margin. In order to achieve successfully stated goal, it is necessary to analyze in detail the nature and organizationaleconomical conditions in which this enterprise is operating, analyze all available resources as well as realized results in production of field crops in previous period.

\section{Methodology}

According to the analyzed data on natural and organizational-economical conditions of production and achieved production results of the observed agricultural enterprise, it can be concluded that the existing available capacities are not being used to a maximum and this has unsatisfactory economic results as a consequence. The realized yield in field crop production is also not at satisfactory level. This is above all the consequence of the outdated agro-technical measurements of production and inadequate organization of work processes.

The models for the optimization of existing production structure have been made in order to project the better results, natural (yields) as well as economical (gross margin). The first model for optimization of the field crop production has started with the current structure consisting of four crop cultures: wheat, maize, sunflower and soybeans, and the optimization in function of maximizing the gross margin was done with the use of linear programming. In order to maximize the use of the available resources the second model was created. This model included sugar beet as a fifth crop culture which demands the most input in terms of both work hours and mechanization per unit of used land.

The models of optimal production structure were created by laying all defined data in the Excel table.

\section{Results and discussion}

In order to estimate the quality of the optimal results (first and second model), their mutual comparison, as well as the comparison with the existing conditions in the agricultural enterprise have been performed.

For that purpose the following indicators were used:

- Sowing structure

- Gross margin per used hectare in RSD (The currency of Serbia)

- Gross margin per full-time employee in RSD (The currency of Serbia)

- The level of usage of the available work time of the full-time employee

The comparison of the current structure with the structure from the first and second model is shown in Chart 1.

Chart 1. The Sowing structure

(in \%)

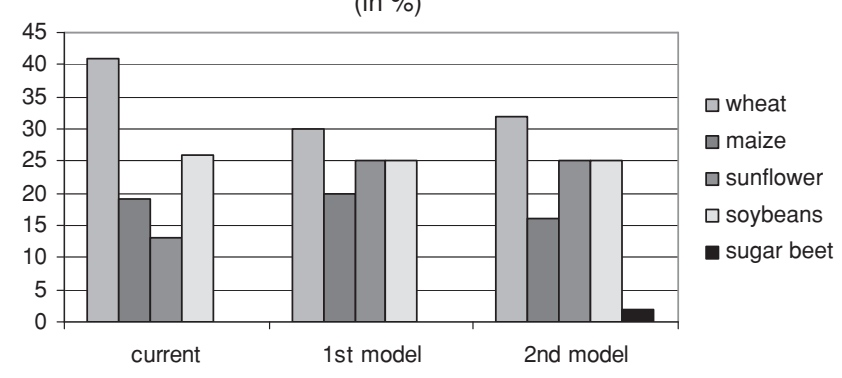

It can be obtained that wheat has the highest contribution in the sowing structure with $42 \%$ in current structure, $30.06 \%$ in first, and $31.96 \%$ in the second model.

The contribution of the maize was the highest in the first model (19.78\%), sunflower in the current structure (13\%), while the soybeans was fairly stable in all three sowing structures (approximately 25\%).

The highest gross margin per hectare of the used land has been realized in the second model and was higher than the current structure by approximately $29.8 \%$ (Chart 2 ).

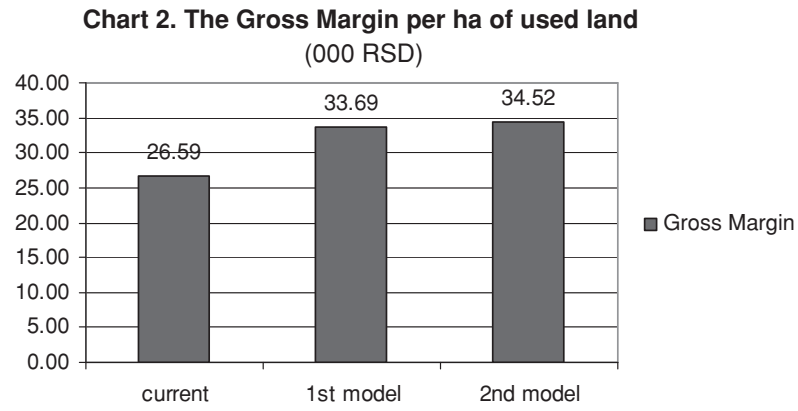

The highest gross margin per full-time employee has been achieved in the second model and is higher than the current by $617,000 \mathrm{RSD}$, and by 64,250 RSD than the first model (Chart 3).

The level of usage of the available work time of the fulltime employee of the first and second model has been shown in chart 4. It is evident that all months during the season of 
Chart 3. The Gross Margin per employee (000 RSD)

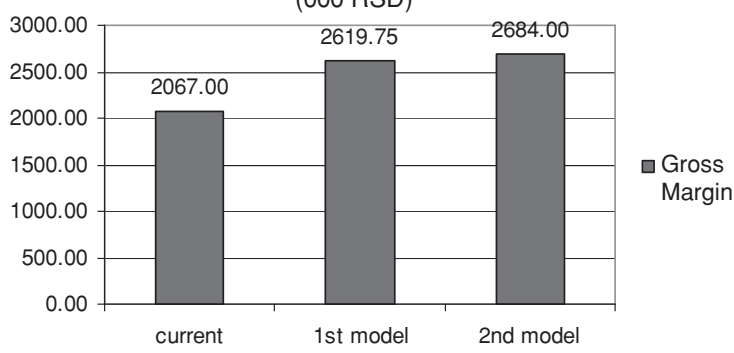

Chart 4. Structure of used time (in \%)

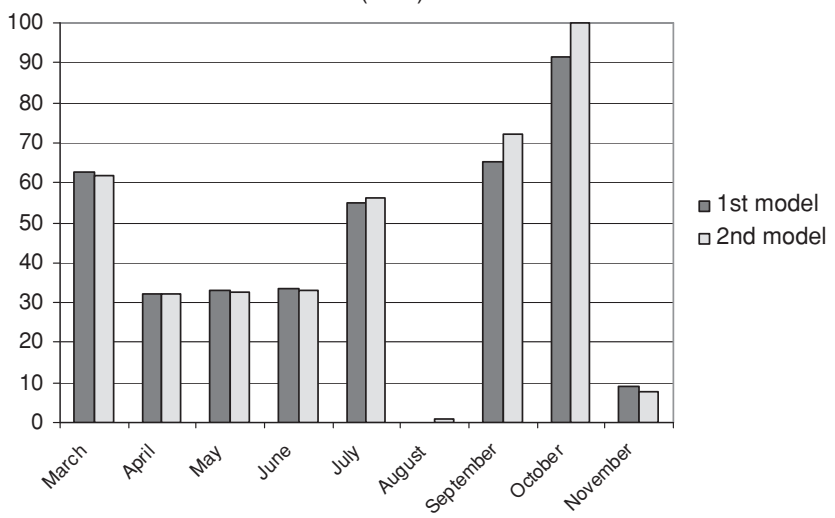

agricultural activities in field crop production show significant unused reserves of the available working time except for October in the second model when all available working time of the employees has been used $100 \%$.

\section{Conclusion}

Regardless of the very favourable natural and organizational-economic conditions for crop production, the analyzed agricultural enterprise does not realize satisfying economic results.

The major characteristics of the production are:

- The enterprise has 311 ha or arable land

- The current full-time employees and mechanization are suitable for completing all necessary work processes

- The crop rotation includes four cultures with average contribution in period 2004-2008 year: wheat (41\%), maize $(19 \%)$, sunflower $(13 \%)$ and soybeans $(26 \%)$

- The realized average gross margin in observed period was 8,268,000 RSD

Considering the above mentioned characteristics of field crop production in the analyzed agricultural enterprise, and with a objective of analyzing the possibilities of improving the operating outcome, two models for optimizing the structure of field crop production were created.

The optimal results of the first model are the following:

- Sowing structure consists of: wheat $(30.6 \%)$, maize (19.78\%), sunflower (25\%) and soybeans (25\%)

- Total gross margin amounts 10,479,711.64 RSD and is higher by $26.75 \%$ in comparison to current structure

- Significant unused reserves of the available full-time employees and mechanization were found.

Optimizing results of the second model:

- The sowing structure consist of: wheat (31.96\%), maize $(16.16 \%)$, sunflower $(25.08 \%)$, soybeans $(25.08 \%)$ and sugar beet $(1.72 \%)$

- Total gross margin amounts 10,736,553.34 RSD and is higher than current structure by $29.86 \%$ and by $2.45 \%$ than the first model

- The limitations of the available work time of the fulltime employees and mechanization were fully satisfied in October - work time peak.

Using the comparative analysis of the obtained results in the first and second model with the results realized in period 2004-2008. year, it was evident the following:

- The greatest gross margin per hectare of used arable land was realized in the second model

- The greatest value of gross margin per full-time employee was achieved in the second model

- The level of usage of the available work time of the full-time employees was the highest in the second model and in October it was $100 \%$.

Referring to the obtained results, it can be concluded that the use of method modelling provides rather good estimation for the contemporary planning and decision making while choosing the structure of field crop production in agricultural enterprise.

\section{References}

1. Bogdanov, Natalija (1998): „Optimalna struktura proizvodnje Srbije u koncepciji njenog budućeg razvoja“, Doktorska disertacija, Poljoprivredni fakultet, Beograd

2. Ceranić, S. (1988): „Model razvoja poljoprivredne proizvodnje na području regiona Južnog Banata“, Doktorska disertacija, Poljoprivredni fakultet, Beograd

3. Chadwick, L. (2000): „The farm management Handbook 2000/2001“, 21st Edition, The Scottish agriculture college, Edinburgh

4. Gogić, P. (2005): „Teorija troškova sa kalkulacijama - u proizvodnji i preradi poljoprivrednih proizvoda, Poljoprivredni fakultet, Beograd

5. Ivkov, Ivana, Todorović, S., Munćan, M. (2008): „Bruto marža kao značajan pokazatelj poslovanja poljoprivrednih gazdinstava“, Simpozijum: Agroekonomska nauka i struka u tranziciji obrazovanja i agroprivrede, Poljoprivredni fakultet, Beograd

6. Krstć, B., Smiljić, S. (2003): „Teorija i praksa sistemskog pristupa poslovnom menadžmentu u poljoprivredi“, Consecco Institut, Beograd

7. Milivojčević, D. (2002): „Formulisanje modela za optimizaciju ratarsko-stočarske proizvodnje u poljoprivrednoj korporaciji Beograd“, Magistarska teza, poljoprivredni fakultet, Beograd

8. Munćan, P. (1991): „Uticaj strukture proizvodnje na racionalno korišćenje sredstava mehanizacije u poljoprivrednim 
gazdinstvima ratarskog smera proizvodnje“, Doktorska disertacija, Poljoprivredni fakultet, Beograd

9. Munćan, P., Živković, D. (2004): „Menadžment rada i proizvodnje u poljoprivredi“", Poljoprivredni fakultet, Beograd

10. Munćan, P., Živković, D. (2006): „Menadžment ratarske proizvodnje“, Poljoprivredni fakultet, Beograd

11. Nikolić, R. (1984): „Optimizacija parametara poljoprivrednih traktora u cilju određivanja racionalnog sastava mašinskog parka“, Doktorska disertacija, poljoprivredni fakultet, Novi Sad

12. Nix, J., Hill, P. (2001): , Farm management pocketbook“, 32nd Edition, Imperial college Wye, London

13. Novković, N. (1989): „Optimiranje poljoprivredne proizvodnje na bazi više kriterijuma optimalnosti“, Doktorska disertacija, Poljoprivredni fakultet, Novi Sad
14. Novković, N., Rodić, Vesna, Vukelić, Nataša (2008): „Linearno programiranje - primeri i zadaci“, Poljoprivredni fakultet, Novi $\mathrm{Sad}$

15. Rodić, Vesna (2001): „Model za optimiranje razvoja poljoprivrede i prehrambene industrije“, Doktorska disertacija, Poljoprivredni fakultet, Novi Sad

16. Šomođi, Š. (1991): „Simulacije u poljoprivredi“, Poljoprivredni fakultet, Novi Sad

17. Tomić, R. (1994): „Modeli porodičnih gazdinstava usmerenih naovčarsku proizvodnju u planinskim područjima Srbije“, Doktorska disertacija, Poljoprivredni fakultet, Beograd

18. Živković, D. (1991): „Ispitivanje mogućnosti veće zastupljenosti useva za proizvodnju biljnih ulja u uslovima SAP Vojvodine“, Doktorska disertacija, Poljoprivredni fakultet, Beograd 